\title{
MANAJEMEN STRATEGI DALAM PEMBERDAYAAN EKONOMI BAGI MASYARAKAT MENENGAH KEBAWAH DALAM RANGKA MENANGKAL PAHAM RADIKALISME DAN TERORISME DI ERA REVOLUSI INDUSTRI 4.0
}

\author{
Adji Seputro \\ Falkutas Ekonomi Universitas Pandanaran \\ ardraseputro@gmail.com
}

\begin{abstract}
Abstrak:pembahasan tentang Ekonomi Pertumbuhan dikaitkan dengan Pemberdayaan UMKM oleh pemerintah saat ini menjadi sangat penting dalam upaya merumuskan kebijakan strategis. Kebijakan Strategis diambil dari konsep Pengembangan Sumber Daya Manusia Indonesia yang sangat beragam di Indonesia dan kaitan dengan Manajemen strategik yakni arah pengembangan UMKM di satu sisi. Sumber Daya Manusia selalu yang dikaitkan dengan sumber daya manusia potensial terutama dari Masyarakat Menengah ke bawah yang diharapkan memiliki peran aktif dalam partisipasi kewarganegaraan. Dalam indeks yang diterbitkan oleh UNDP (2017) partisipasi ekonomi dan sosial politik mereka sebagai warga negara jauh melampaui negara- negara lain di Asia. Tantangan yang tidak mudah bagi sumber daya manusia pada UMKM - UMKM saat ini di era revolusi industri 4.0 adalah integrasi pemanfaatan internet dengan lini produksi yang memanfaatkan kecanggihan teknologi dan informasi. Pendalaman konsep Manajemen Strategik yang dikaitkan dengan Sumber Daya Manusia pada UMKM di Indonesia memiliki semangat dan peran penting dalam pembangunan ekonomi. Secara kasar hal itu dibuktikan dengan tingginya partisipasi pemuda di sektor usaha.
\end{abstract}

Kata Kunci : Manajemen Stategik ; Sumber Daya Manusia ; Pemberdayaan ekonomi UMKM ; Deradikalisasi Dan terorisme

\section{PENDAHULUAN}

Belum kokohnya fundamental perekonomian Indonesia mendorong pemerintah untuk membangun struktur ekonomi dengan mempertimbangkan keberadaan Usaha Mikro, Kecil dan Menengah (UMKM). Sektor ini telah terbukti memberikan lapangan kerja dan memberikan kesempatan bagi UKM untuk berkembang di masyarakat. Keberadaan UMKM tidak dapat diragukan karena terbukti mampu bertahan dan menjadi penggerak ekonomi, terutama setelah krisis ekonomi.
Produk, layanan jasa, biaya, maupun sumber daya manusia. Dari lima Prinsip Pemberdayaan UMKM Menurut Bab II Pasal 4 dan Pasal 5 UU No.20/2008 tentang UMKM , prinsip dan tujuan pemberdayaan UMKM bermuara pada salah satu peningkatkan peran UMKM dalam pembangunan daerah, penciptaan lapangan kerja, pemerataan pendapatan, pertumbuhan ekonomi, dan pengentasan kemisikinan. Disisi lain, UMKM juga menghadapi banyak sekali permasalahan, yaitu terbatasnya modal kerja, Sumber Daya Manusia yang rendah, dan 
minimnya penguasaan ilmu pengetahuan serta teknologi (Sudaryanto dan Hanim, 2002). Kendala lain yang dihadapi UMKM adalah keterkaitan dengan prospek usaha yang kurang jelas serta perencanaan, visi dan misi yang belum mantap. Hal ini terjadi karena umumnya UMKM bersifat income gathering yaitu menaikkan pendapatan, dengan ciri-ciri sebagai berikut: merupakan usaha milik keluarga, menggunakan teknologi yang masih relatif sederhana, kurang memiliki akses permodalan (bankable), dan tidak ada pemisahan modal usaha dengan kebutuhan pribadi. Pemberdayaan UMKM di tengah arus globalisasi dan tingginya persaingan membuat UMKM harus mampu mengadapai tantangan global, seperti meningkatkan inovasi produk dan jasa, pengembangan sumber daya manusia dan teknologi, serta perluasan area pemasaran. Hal ini perlu dilakukan untuk menambah nilai jual UMKM itu sendiri, utamanya agar dapat bersaing dengan produk-produk asing yang kian membanjiri sentra industri dan manufaktur di Indonesia, mengingat UMKM adalah sektor ekonomi yang mampu menyerap tenaga kerja terbesar di Indonesia (Sudaryanto, 2011).

Meskipun UMKM dikatakan mampu bertahan dari adanya krisis global namun pada kenyataannya permasalahan-permasalahan yang dihadapi sangat banyak dan lebih berat. Hal itu dikarenakan selain dipengaruhi secara tidak langsung krisis global tadi, UMKM harus pula menghadapi persoalan domestik yang tidak kunjung terselesaikan seperti masalah upah buruh, ketenaga kerjaan dan pungutan liar, korupsi dan lain-lain. Permasalahan lain yang dihadapi UMKM, yaitu adanya liberalisasi perdagangan, seperti pemberlakuan ASEAN- China Free Trade Area (ACFTA) yang secara efektif telah berlaku tahun 2010. Disisi lain, Pemerintah telah menyepakati perjanjian kerja sama ACFTA ataupun perjanjian lainnya, namun tanpa mempertimbangkan terlebih dahulu kesiapan UMKM agar mampu bersaing. Sebagai contoh kesiapan kualitas produk, harga yang kurang bersaing, kesiapan pasar dan kurang jelasnya peta produk impor sehingga positioning persaingan lebih jelas. Kondisi ini akan lebih berat dihadapi UMKM Indonesia pada saat diberlakukannya ASEAN Community yang sudah dilaksanakan dari tahun 2015. Apabila kondisi ini dibiarkan, UMKM yang disebut mampu bertahan hidup dan tahan banting pada akhirnya akan bangkrut juga. Oleh karena itu, dalam upaya memperkuat UMKM sebagai fundamental ekonomi nasional, perlu kiranya diciptakan iklim investasi domestik yang kondusif dalam upaya penguatan pasar dalam negeri agar UMKM dapat menjadi penyangga (buffer) perekonomian nasional. Pemberdayaan Ekonomi UMKM adalah langkah awal dalam meningkatkan potensi daya saing UMKM. Pemerintah mempunyai peran strategik dalam membuat kebijakan penting yang setidaknya mampu mengurai faktor faktor yang menjadi tantangan bagi UMKM yakni agar dapatmemanfaatkan keuntungan melalui kerjasama dengan perusahaan multinasional tersebut (yuhua \& Bayhaqi, 2013). Pertama , UMKM perlu meningkatkan kemampuan teknis dan operasional untuk mencapai standar global perusahaan 
multinasional. Terkait dengan hal tersebut, UMKM perlu mendapatkan akses modal yang memadai agar dapat melakukan investasi pada proses produksi. Tantangan selanjutnya adalah pada sumber daya manusia (SDM). Dengan budaya dan struktur kerja informal, dan tidak adanya rencana karir yang jelas, UMKM sangat sulit dalam meningkatkan kualitas SDM atau menarik SDM yang profesional. Sementara perubahan dalam business Revolusi industri keempat disebut sebagai revolusi industri yang akan mengubah pola dan relasi antara manusia dengan mesin. Inovasi yang diawali dengan besarnya data di internet dan penggunaan cloud mengubah produk industri. Serta mengubah proses produksi dan pemasaran produk. Bahkan mengubah gaya hidup masyarakat karena produk dari revolusi industri ini dapat dilihat penggunaannya di kehidupan sehari-hari. Secara umum revolusi industri keempat ditandai dengan full automation, proses digitalisasi, dan penggunaan alat elektronik dengan sistem informatika. Menurut Sommer, 2015 (dalam Roblek, Mesko, Krapez, 2016), perubahan akibat inovasi tersebut akan berdampak pada industri manufaktur, sektor pelayanan dan jasa, serta kebijakan pemerintah. Bahkan akan mempengaruhi relasi antara customer dengan perusahaan, serta relasi masyarakat umum dengan pemimpin negaranya. Bentuk produk dari revolusi industri 4.0 yaitu akan semakin berkembangnya teknologi untuk 3D printing, bahkan bukan saja untuk mencetak produk, ada pula mencetak organ tubuh. Produk yang berkembang saat ini seperti semakin mudahnya untuk mengakses layanan secara online, baik belanja online, melakukan service kendaraan online, memesan makanan, bahkan pemeriksaan kesehatan secara online. Harga yang ditawarkan untuk berbagai layanan dan jasa tersebut akan semakin murah dengan semakin masifnya inovasi yang dibuat oleh setiap perusahaan. Termasuk proses persaingan yang ketat antar perusahaan akan berakibat persaingan terkait harga dan menguntungkan pelanggan. Revolusi industri 4.0 tidak dapat ditolak karena telah dilihat bahwa penggunaan berbagai macam produk revolusi industri 4.0 telah dirasakan saat ini. Pada revolusi industry sebelumnya biasanya selalu didominasi oleh negara-negara Eropa dan Amerika yang memiliki berbagai modal yang lebih besar. Akan tetapi, revolusi industri 4.0 memungkinkan setiap negara untuk mengembangkan diri dan meningkatkan kemampuannya secara internal. Karena batas-batas negara akan semakin berkurang dengan masifnya pertukaran informasi di era digital.

Berdasarkan kondisi empirik asusmsi diatas tentang UMKM berbasis manajemen strategik dan kerangka teori yang mendukung pembelajaran UMKM, maka fokus penelitian ini berupaya untuk mendeskripsikan nilai-nilai Management Startegik serta MSDM Strategik yang membentuk sikap dan perilaku pelaku UMKM dalam mengelola UMKM dengan nilai nilai keyakinan pemberdayaan ekonomi UMKM sebagai penguat ekonomi masyarakat yang menjadi landasan kuat membangun ikatan utama menangkal daya mental negative masyarakat dan mencegah paham negative seperti radikalisme dan 
terorisme akibat peningkatan daya saing UMKM di Era Revolusi Industri 4.0. berpendapat bahwa strategi adalah pola tindakan utama yang dipilih untuk mewujudkan visi organisasi, melalui misi. Strategi membentuk pola pengambilan keputusan dalam mewujudkan visi organisasi, Dengan tindakan berpola, perusahaan dapat mengerahkan dan mengarahkan seluruh sumber daya organisasi secara efektif ke perwujudan visi organisasi. Sebagai contoh, perusahaan yang memilih differentiation strategy akan memilih pola tindakan untuk menjadikan perusahaan berbeda karena keunggulannya di dalam persaingan. Sedangkan Manajemen strategik adalah serangkaian keputusan dan tindakan manajerial yang menentukan kinerja perusahaan dalam jangka panjang. 2. Pembahasan Konsep Manajemen Strategik Strategi berasal dari bahasa Yunani strategeia, yang berarti kepemimpian dalam ketentaraan. Menurut Freddy (1997), strategi merupakan alat untuk mencapai tujuan. Dalam perkembangannya, konsep mengenai strategi terus berkembang. Sedangkan Mulyadi (2001) Strategi membentuk pola pengambilan keputusan dalam mewujudkan visi organisasi, Dengan tindakan berpola, perusahaan dapat mengerahkan dan mengarahkan seluruh sumber daya organisasi secara efektif ke perwujudan visi organisasi. Sebagai contoh, perusahaan yang memilih differentiation strategy akan memilih pola tindakan untuk menjadikan perusahaan berbeda karena keunggulannya di dalam persaingan. Strategi dirumuskan untuk menggalang berbagai sumber daya organisasi dan mengarahkannya ke pencapaian visi organisasi. Tanpa strategi yang tepat, sumber daya organisasi akan terhambur konsumsinya, sehingga akan berakibat

Berdasarkan kondisi empirik asusmsi diatas tentang UMKM berbasis manajemen strategik dan kerangka teori yang mendukung pembelajaran UMKM, maka fokus penelitian ini berupaya untuk mendeskripsikan nilai-nilai Management Startegik serta MSDM Strategik yang membentuk sikap dan perilaku pelaku UMKM dalam mengelola UMKM dengan nilai nilai keyakinan pemberdayaan ekonomi UMKM sebagai penguat ekonomi masyarakat yang menjadi landasan kuat membangun ikatan utama menangkal daya mental negative masyarakat dan mencegah paham negative seperti radikalisme dan terorisme akibat peningkatan daya saing UMKM di Era Revolusi Industri 4.0. berpendapat bahwa strategi adalah pola tindakan utama yang dipilih untuk mewujudkan visi organisasi, melalui misi. Strategi membentuk pola pengambilan keputusan dalam mewujudkan visi organisasi, Dengan tindakan berpola, perusahaan dapat mengerahkan dan mengarahkan seluruh sumber daya organisasi secara efektif ke perwujudan visi organisasi. Sebagai contoh, perusahaan yang memilih differentiation strategy akan memilih pola tindakan untuk menjadikan perusahaan berbeda karena keunggulannya di dalam persaingan. Sedangkan Manajemen strategik adalah serangkaian keputusan dan tindakan manajerial yang menentukan kinerja perusahaan dalam jangka panjang. 


\section{PEMBAHASAN}

Konsep Manajemen Strategik Strategi berasal dari bahasa Yunani strategeia, yang berarti kepemimpian dalam ketentaraan. Menurut Freddy (1997), strategi merupakan alat untuk mencapai tujuan. Dalam perkembangannya, konsep mengenai strategi terus berkembang. Sedangkan Mulyadi (2001) Strategi membentuk pola pengambilan keputusan dalam mewujudkan visi organisasi, Dengan tindakan berpola, perusahaan dapat mengerahkan dan mengarahkan seluruh sumber daya organisasi secara efektif ke perwujudan visi organisasi. Sebagai contoh, perusahaan yang memilih differentiation strategy akan memilih pola tindakan untuk menjadikan perusahaan berbeda karena keunggulannya di dalam persaingan. Strategi dirumuskan untuk menggalang berbagai sumber daya organisasi dan mengarahkannya ke pencapaian visi organisasi. Tanpa strategi yang tepat, sumber daya organisasi akan terhambur konsumsinya, sehingga akan berakibat pada kegagalan organisasi dalam mewujudkan visinya. Dalam lingkungan bisnis yang kompetitif, strategi memainkan peran penting dan menentukan dalam mempertahankan kelangsungan hidup dan pertumbuhan perusahaan. (Mulyadi, 2007). Sedangkan Manajemen strategik adalah serangkaian keputusan dan tindakan manajerial yang menentukan kinerja perusahaan dalam jangka panjang. Manajemen strategis meliputi pengamatan lingkungan, perumusan strategi (perencanaan strategis dan perencanaan jangka panjang), implemetasi strategi, dan evaluasi serta pengendalian. Manajemen strategis menekankan pada pengamatan dan evaluasi peluang dan ancaman lingkungan dengan melihat kekuatan dan kelemahan perusahaan. (Wheelen dan Hunger, 2001: 4). Manajemen strategis adalah suatu proses yang digunakan oleh manajer dan karyawan untuk merumuskan dan mengimplementasikan strategi dalam penyediaan customer value terbaik untuk mewujudkan visi perusahaan. Pada dasarnya manajemen strategis adalah suatu upaya manajemen dan karyawan untuk membangun masa depan perusahaan. Strategi adalah pola tindakan utama yang dipilih untuk mewujudkan visi perusahaan, melalui misi. (Mulyadi, 2007:38)

\section{Perumusan Strategi}

Termasuk mengembangkan visi dan misi, mengidentifikasi peluang eksternal organisasi dan ancaman, menentukan kekuatan dan kelemahan internal, menetapkan tujuan jangka panjang, menghasilkan strategi alternatif, dan memilih strategi tertentu untuk mengejar. Strategi isu formulasi termasuk memutuskan bisnis apa yang baru masuk, apa bisnis untuk meninggalkan, apakah akan bergabung atau membentuk usaha patungan, dan bagaimana untuk menghindari pengambilalihan bermusuhan. David \& David (2015:39).

\section{Implementasi Strategi.}

Memerlukan suatu perusahaan untuk membangun objectives tahunan, menyusun kebijakan, memotivasi karyawan, dan mengalokasikan sumber daya sehingga strategi yang dirumuskan dapat dilaksanakan. Implementasi strategi termasuk mengembangkan strategi - budaya yang mendukung, menciptakan struktur organisasi yang efektif, mengarahkan upaya 
pemasaran, menyiapkan anggaran, mengembangkan dan menggunakan sistem informasi, dan menghubungkan kompensasi karyawan dengan kinerja organisasi. David \& David (2015:40).

\section{Evaluasi Strategi}

Evaluasi Strategi merupakan tahap akhir dalam manajemen strategis. Manajer sangat membutuhkan untuk tahu kapan strategi tertentu tidak bekerja dengan baik; evaluasi strategi adalah sarana utama untuk memperoleh informasi ini. Semua strategi adalah subyek modifikasi masa depan karena faktor eksternal dan internal terus berubah. Menurut David \& David (2015:40) Terdapat tiga kegiatan evaluasi strategi fundamental yaitu:

1. Meninjau faktor eksternal dan internal yang dasar untuk strategi saat ini.

2. Mengukur kinerja.

3. Mengambil tindakan korektif.

\section{b. Pemberdayaan Ekonomi UMKM dalam Konsep Strategis Peningkatan Daya Saing.}

Mengingat peran strategis UMKM dan masih terbatasnya kemampuan UMKM untuk berkembang, maka saat ini pengembangan usaha kecil merupakan salah satu strategi yang diambil Pemerintah dalam rangka pertumbuhan ekonomi. Peran strategis UMKM ini maka perlu adanya pemberdayaan UMKM agar mampu tumbuh dan berkembang menjadi usaha yang tangguh dan mandiri.

Pengembangan adalah upaya yang dilakukan oleh Pemerintah, Pemerintah Daerah, Dunia Usaha, dan masyarakat untuk memberdayakan Usaha Mikro, Kecil, dan Menengah melalui pemberian fasilitas bimbingan pendampingan dan bantuan perkuatan untuk menumbuhkan dan meningkatkan kemampuan dan daya saing Usaha Mikro, Kecil, dan Menengah.

Pemberdayaan

UMKM diselenggarakan sebagai kesatuan dan pembangunan perekonomian nasional untuk mewujudkan kemakmuran rakyat. Dengan dilandasi dengan asas kekeluargaan, upaya pemberdayaan UMKM merupakan bagian dari perekonomian nasional yang diselenggarakan berdasar atas demokrasi ekonomi dengan prinsip kebersamaan, berkelanjutan, berwawasan lingkungan, kemandirian, keseimbangan kemajuan, dan kesatuan ekonomi nasional untuk kesejahteraan seluruh rakyat Indonesia. Asas Kebersamaan adalah asas yang mendorong peran seluruh UMKM dan Dunia Usaha secara bersama-sama dalam kegiatannya untuk mewujudkan kesejahteraan rakyat. Asas Efisiensi adalah asas yang mendasari pelaksanaan pemberdayaan UMKM dengan mengedepankan efisiensi berkeadilan dalam usaha untuk mewujudkan iklim usaha yang adil, kondusif, dan berdaya saing. Tujuan Pembangunan UMKM telah menjadi referensi penting bagi pembangunan di Indonesia, mulai dari tahap perencanaan seperti yang tercantum pada Rencana Pembangunan Jangka Menengah (RPJM) hingga pelaksanaannya. Walaupun mengalami kendala, namun pemerintah memiliki komitmen untuk mencapai tujuan-tujuan ini dan dibutuhkan kerja keras serta kerjasama dengan seluruh pihak, termasuk masyarakat madani, pihak swasta dan lembaga donor. Untuk mencapai Tujuan Pembangunan 
Milenium yang pertama yaitu menghapuskan tingkat kemiskinan dan kelaparan, Pemerintah Indonesia telah membuat berbagai kebijakan salah satunya adalah pemberdayaan ekonomi kerakyatan dalam hal ini UMKM dan koperasi. Peranan UMKM membantu perekonomian suatu daerah. Kehadiran UMKM tidak saja dalam rangka peningkatan pendapatan tetapi juga dalam rangka pemerataan pendapatan. Pemberdayaan UMKM merupakan langkah yang strategis dalam meningkatkan dan memperkuat dasar kehidupan perekonomian dari sebagian besar rakyat Indonesia, khususnya melalui penyediaan lapangan kerja dan mengurangi kesenjangan serta mengurangi tingkat kemiskinan.

\section{c. Manajemen Strategik Dalam Pemberdayaan Ekonomi UMKM}

Dalam menunjang kegiatan ekonomi Nasional, terutama dalam hal untuk mengatasi kemiskinan, pengangguran dan kesenjangan antar sektor, maka keberadaan UMKM sangat strategis. Namun dalam melaksanakan peran strategis UMKM tersebut tidak jarang dijumpai kendala baik praktis maupun non praktis, baik secara internal maupun eksternal. Tinjaun Managemen Strategis UMKM saat ini diarahkan terutama dalam tinjauan MSDM Stratgeis yang dikaitkan dalam mempersiapkan konsep pemberdaaan Ekonomi pada UMKM menghadapi revolusi industry 4.0, sedikitnya ada tiga hal yang yang perlu diperhatikan semua pihak. Pertama adalah kualitas, yaitu upaya menghasilkan SDM yang berkualitas agar sesuai dengan kebutuhan pasar kerja yang berbasis teknologi digital. Kedua, adalah masalah kuantitas, yaitu menghasilkan jumlah SDM yang berkualitas, kompeten dan sesuai kebutuhan industri. Ketiga, adalah masalah distribusi SDM berkualitas yang masih belum merata.

Mengenai upaya peningkatan kompetensi dan produktivitas SDM, perlu dilakukan upaya yang masif melalui lembaga-lembaga pelatihan kerja, badan setifikasi profesi yang sedang dilakukan pemerintah melalui pelatihan di Balai Latihan Kerja dan program-program pemagangan. Untuk menjawab tantangan era revolusi industri 4.0 tidak cukup hanya dengan literasi manusia lama, yang hanya mendasarkan pada kemampuan membaca, menulis dan menghitung. Menurut Aoun (2017), untuk mendapatkan SDM yang kompetitif dalam industri 4.0, kurikulum pendidikan harus dirancang agar out putnya mampu menguasi literasi baru, yaitu:

1. Literasi data, yaitu kemampuan membaca, menganalisis dan memanfaatkan informasi big data dalam dunia digital

2. Literasi teknologi, yaitu memahami cara kerja mesin, aplikasi teknologi (coding, artificial intelligence dan engineering principles,

3. Literasi manusia, humanities, komunikasi dan desain.

Dalam perspektif literasi manusia, tujuananya adalah agar manusia dapat berfungsi dengan baik di lingkungan manusia yang semakin dinamis. Perguruan tinggi perlu mencari cara baru untuk mengembangkan kapasitas kognisi manusia, yaitu : higher order mental skills, berfikir kritis dan sistemik. Dalam industry 4.0, modal dasar SDM yang harus dimiliki adalah : keterampilan yaitu kepemimpinan 
(leadership) dan bekerja dalam team (teamwork), kelincahan dan kematangan budaya (cultural agility), dengan latar belakang budaya yang berbeda tetap bisa bekerjasama, dan entreprenurship (termasuk sociopreneurship) Namun demikian modal fundamental SDM yang selama ini dianggap sukses dalam praktek MSDM pada UMKM harus tetap diperhatikan. Lebih jelas lagi bahwa, untuk melaksanakan secara maksimal pemberdayaan ekonomi UMKM memang diperlukan sumber daya manusia (SDM) yang bisa diandalkan, dalam hal ini adalah pimpinan dari berbagai lembaga atau institusi yang berwewenang baik pihak swasta maupun pemerintah, mulai dari membuat perencanaan strategis, implementasi strategis sampai kepada evalusi sesuai dengan langkah-langkah penerapan manajemen strategik itu sendiri.

\section{d. Paham Radikalisme dan Terorisme}

Radikalisme adalah sebuah paham atau aliran yang sering berpandangan kolot, bertindak dengan menggunakan kekerasan dan bersifat ekstrim untuk merealisasikan cita-citanya (sadili Hasan:1984). Dalam beberapa literatur disebutkan bahwa radikalisme adalah suatu paham yang menginginkan sebuah perubahan atau pembauran dengan cara drastis hingga ke titik yang paling akar. Terorisme bukan persoalan siapa pelaku, kelompok dan jaringannya. Namun, lebih dari itu terorisme merupakan tindakan yang memiliki akar keyakinan, doktrin dan ideologi yang dapat menyerang kesadaran masyarakat. Tumbuh suburnya terorisme tergantung di lahan mana ia tumbuh dan berkembang. Jika ia hidup di tanah gersang, maka terorisme sulit menemukan tempat, sebaliknya jika ia hidup di lahan yang subur maka ia akan cepat berkembang. Radikalisme merupakan embrio lahirnya terorisme. Radikalisme merupakan suatu sikap yang mendambakan perubahan secara total dan bersifat revolusioner dengan menjungkirbalikkan nilai-nilai yang ada secara drastis lewat kekeraan (violence) dan aksi-aksi yang ekstrem.

\section{e. Koneksivitas Pemberdayaan Ekonomi UMKM dengan Paham Radikalisme dan Terorisme di Era Revolusi Industri 4.0.}

Menurut Mello (253:2015) sedikitnya terdapat tiga dampak bagi organisasi untuk merespon perubahan teknologi baru, yaitu : (1) perlunya meningkatkan skills dan work habits pegawai, tersingkirnya jabatan tingkat rendah dan level manajerial, (3) hirarki berkurang, lebih berorietasi entasi pada kerjasama atau kolaborasi dan (4) Kehidupan pekerja pada era industry 4.0 didominasi oleh selfdirected striving for personally valued career outcomes Hirschi et.al (2016).

The McKinsey Global Institute (2017) memperkirakan bahwa "50\% dari lapangan pekerjaan berpotensi untuk diotomatisasi dengan mengadaptasi teknologi baru. Meskipun kurang dari 5\% pekerjaan dapat sepenuhnya otomatis, namun $60 \%$ dapat memiliki $30 \%$ atau lebih dari kegiatan mereka dapat diotomatisasi secara teknis. Dinamika dunia industri mengalami perkembangan secara pesat dimulai dari Revolusi Industri pertama dengan ditemukannya mesin mesin 
pada sektor sektor manufaktur, sektor pertanian,sektor pertambangan pada era 1750- 1850 secara langsung sangat mempengaruhi pembatasan tenaga manusia menjadi otamasi sistem dengan digunakannya mesinmesin otomatis pengganti tenaga manusia, efek langsung sangat terasa dikala dominasi sektor tenaga kerja yang bersifat padat karya berkurang dimana peran manusia akan berkurang.

Dampak sosial dan lingkungan dari proses proses yang tercipta di era revolusi Industri 4.0 ini adalah satu hal yang ironis dibalik kemudahan yang ditawarkan, Revolusi Industri 4.0 menyimpan berbagai dampak negatif,

$$
\text { diantaranya }
$$

ancaman pengangguran akibat otomatisasi, kerusakan alam akibat ekspoitasi industri, serta maraknya hoax akibat mudahnya penyebaran informasi. Selain membawa dampak persoalan lingkungan, revolusi industri juga akan meninggalkan persoalan yang berkaitan dengan hilangnya nilainilai sosial humaniora. Generasi milenial, generasi yang lahir pada sekitar tahun 1980-2000an, sudah menunjukkan adanya gejala-gejala degradasi mental. Gaya hidup konsumerisme, kebebasan yang tanpa batas, serta hilangnya perilaku etis dimedia sosial adalah serangkaian contoh dari degradasi tersebut.

Pemberdayaan ekonomi merupakan salah satu pendekatan strategis dalam deradikalisasi dan pencegahan terorisme. Hubungan antara keamanan dan pembangunan "secara khusus terbukti ketika melihat di luar penafsiran tradisional keamanan nasional atas human security, termasuk ancaman lingkungan, ekonomi, kesehatan dan kriminal lainnya." Pendekatan ini diterapkan di beberapa negara dalam kebijakan kontra terorisme mereka. John Horgan menyatakan pentingnya memisahkan individu dan kelompok kekerasan dari yang lain (disengagement). Horgan melanjutkan memahami proses from involvement ...to disengagement" merupakan pendekatan baru psikologi teroris melalui sharing pengalaman para pelaku terorisme bagaimana mereka terlepas dari kelompok dan sel jaringan. Keputusan mereka untuk terlepas dari kelompok lama memiliki beragam alasan yang menarik untuk dikaji melalui multidimensi keilmuan. Dalam pengalaman di Indonesia, disengagement para mantan nara pidana yang notabene adalah kaum muda dan berpotensi melakukan effort terbaik setelah di luar penjara.

Pemberdayaan ekonomi bisa dikatakan sebagai salah satu pendekatan dan instrumen untuk pemisahan ini. SDM yang beorientasi radikal bisa diarahkan dalam pengembangan konsep usaha mandiri dalam bingkai pemberdayaan UMKM. Dan yang lebih terbuka dan bersedia bekerjasama dengan pemerintah dan masyarakat dalam kegiatan kewirausahaan dan bekerja di sektor UMKM Dalam pembahasan tentang radikalisme dan terorisme ada beberapa faktor yang menjadi penyebab munculnya radikalisme dan terorisme, dan salah satu faktor yang paling urgen adalah faktor ekonomi dengan indikasi bahwa tingkat kemiskinan yang begitu tinggi, angka pengangguran juga sangat tinggi, dan, ketidakadilan sosial dalam bentuk terjadinya kesenjangan sosial ekonomi, maka 
dalam kondisi seperti itu dalam iklim ketidakpuasan secara sosial dan ekonomi, tidak dapat dihindarkan sangat terbuka ruang bagi individu maupun kelompok tertentu untuk mencari solusi atau mencari alasan sebagai pembenaran atas tindakan anarkis mereka, dengan indikasi awal memiliki paham radikalisme yang berujung pada aksi teror.

Pada Sidang Umum PBB September 2014, Presiden AS Barack Obama menyatakan bahwa pendekatan kewirausahaan sangat strategis dalam mencegah dan mengatasi radikalisme dan terorisme. Steven R. Koltai dari Brookings.

Institute mengutip pernyataan Barack Obama soal pentingya kewirausahaan bagi pondasi perdamaian yang lebih permanen. Koltai menyatakan bahwa "entrepreneurship is a job-creating machine, and jobs provide the growth and economic hope that are the foundation of peaceful, civil societies " Kewirausahaan adalah mesin yang menciptakan pekerjaan, dan pekerjaanpekerjaan mendorong pertumbuhan dan harapan ekonomi yang merupakan pondasi masyarakat sipil yang damai.

\section{Program}

penguatan

keterampilan ekonomi kaum muda serta UMKM penting tidak hanya dalam rangka mencegah dan menanggulangi terorisme, tetapi juga untuk mengatasi masalah sosial, keamanan perbatasan, dan kriminalitas. Secara internasional posisi kaum muda Indonesia menempati level menengah dalam berbagai aspek. Tantangan besar terdapat pada pada aspek kesempatan ekonomi di era revolusi industry 4.0 menjadi alat counter efektive dalam upaya menahan laju gerak signifikansi pertumbuhan kaum muda akan paham radikalisme dan terorisme.

\section{Kesimpulan}

a. Kebijakan pemberdayaan ekonomi UMKM diharapkan mampu menunjukan potensi keberhasilan untuk mengatasi dan mencegah terorisme serta sangat berpotensi mengurai masalah masalah fundamental terutama disektor ekonomi.

b. Program ekonomi dilakukan secara jangka pendek harus dilanjutkan dengan Aspek Manajemen Strategik dalam mengembangkan Manajemen Sumber Daya Manusia Strategik harus memperhatikan aspek keberlanjutan Kerja sama multistakeholder menjadi kebutuhan krusial dalam membangun pemberdayaan ekonomi secara jangka panjang dan komprehensif.

c. Kerja sama ini diharapkan dalam upaya pemberdayaan ekonomi UMKM bisa mencapai sasaran yang diinginkan.

d. d. Tantangan besar terdapat pada pada aspek kesempatan ekonomi di era revolusi industry 4.0 menjadi alat counter efektive dalam upaya menahan laju gerak signifikansi pertumbuhan Sumber Daya Manusia yang akan paham radikalisme dan terorisme.

\section{DAFTAR PUSTAKA}

Aoun, J.E. (2017). Robot-proof: higher education in the age of artificial intelligence. US: MIT Press.

Assery, S. 2009. Strategi Mempercepat 
Pemberdayaan UMKM. Harian Suara Merdeka, 27 Mei 2009.

David, R Fred. 2012. Strategic Management Concepts \& Cases. Pearson Academic; 14th edition.

Departemen Pengembangan UMKM Bank Indonesia. 2016. Pemetaan dan Strategi Peningkatan Daya Saing UMKM Dalam Menghadapi Masyarakat Ekonomi ASEAN (MEA) 2015 dan Pasca MEA 2025. Diakses dari www.bi.go.id pada tanggal 16 Oktober 2016.

Eelco Kessels and Christina Nemr, "Countering Violent Extremism and Development Assistance entrepreneurship/ Harvey W. Kushner, Encyclopedia of Terrorism, London : Sage Publication, 2003.

Hirschi \& Läge. 2007. Various Grade Readiness. Journal of Vocational Behavior.

Identifying Synergies, Obstacles, and Opportunities," Policy Brief, February 2016, Global Center on Cooperative Security. Accessed on January 04, 2018 from http://www.alobalcenter.ora/w pcontent/uploads/2016/01/Feb2016 -CVE-and-Developmentpolicybrief.pdf.

John G. Horgan, "Psychology of Terrorism: Introduction to the Special Issue," American Psychologist, 2017, Vol. 72, No. 3, hal. 201.

John Horgan et al, "Walking away: the disengagement and deradicalization of a violent right-wing extremist,"Behavioral Sciences of Terrorism and Political Aggression, 2016, Society for Terrorism Research.

Kasali, Rhenald. 2011. Membidik Pasar Indonesia: Segmentasi, Targeting, dan Positioning. Jakarta : PT
Gramedia PustakaUtama.

McKinsey Global Institute, (2017). The Archipelago Economy: Unleashing Indonesia's Potential. McKinsey \& Company.

Mello, A. Jeffrey (2015), Strategic Human Resource Management, 4th

Edition, Cengage Learning Publisher.

Mulyadi. 2001. Balance Scorecard: alat Manajemen Kontemporer Untuk Pelipatganda Kinerja Keungan Perusahaan. Salemba Empat. Jakarta. Rangkuti, Freddy. 2009. Strategi Promosi yang Kreatif dan Analisis Kasus Integrated Marketing Communication. Jakarta. PT. Gramedia Pustaka Utama.

Robbins,P. 2008. Organizational Behaviour, Tenth Edition (Perilaku Organisasi Ke Sepuluh), alih bahasa Drs. Benyamin Molan. Salemba Empat: Jakarta.

Roblek, V., Meško, M., \& Krapež, A. (2016). A Complex View of Industry 4.0. SAGE Open, 6(2), 215824401665398. http://dx.doi.org/10.1177/2158 244016653987.

Sijabat, S. 2008. Potret Iklim Usaha Pemberdayaan UMKM. Infokop, 16. 1- 17.

Sijabat, S. 2008. Potret Iklim Usaha Pemberdayaan UMKM. Infokop.

Steven R. Koltai, "Fighting ISIS with Entrepreneurship," 7 Oktober 2014. Diakses pada 30 Januari 2018 dari https://www.brookings.edu/bl og/fixgov/2014/10/07/fighting -isiswith

Sudaryanto dan Hanim, Anifatul. 2002. Evaluasi kesiapan UKM Menyongsong Pasar Bebas Asean 
(AFTA): Analisis Perspektif dan Tinjauan Teoritis. Jurnal Ekonomi Akuntansi dan Manajemen, Vol 1 No 2, Desember 2002.

\section{Sudaryanto. 2011. Strategi Pemberdayaan UMKM Menghadapi Pasar Bebas Asean. Badan Kebijakan Fiskal Kemenkeu RI, Jakarta. Fakultas Ekonomi Negeri Jember.}

The Global Youth Wellbeing Index 2017" diakses pada 30 Januari 2018 dari dari https://www.vouthindex.ora/co untrv/indonesia. Undang-Undang No. 19 tahun 2003, tentang Badan Usaha Milik Negara (BUMN) pasal 88.

Undang-Undang Republik Indonesia Nomor 20 Tahun 2008 tentang Usaha Mikro, Kecil dan Menengah.
UNDP United Nations Development Programme, "Human Development Report," United Nations Development Programme (UNDP), New York, 2017 UU.

No.15 Tahun 2003 tentang Pemberantasan Tindak Pidana Terorisme.

UU No.15 Tahun 2003 tentang Pemberantasan Tindak Pidana Terorisme Wheelen Thomas.L, Hunger J. David, 2001.Strategic Management and Business Strategy, 10-th edition, Pearson International Edition Yuhua, Z., \& Bayhaqi, A. (2013). SME's participation in global production chains: APEC.

Yuhua, Z., dan Bayhaqi, A. (2013). SME's Participation in Global Production Chains. APEC: Singapore. 